\title{
NCI's provocative questions on cancer: some answers to ignite discussion
}

\author{
Mikhail V. Blagosklonny ${ }^{1}$ \\ ${ }^{1}$ Department of Cell Stress Biology, Roswell Park Cancer Institute, BLSC, L3-312, Elm and Carlton Streets, Buffalo, NY, \\ 14263, USA
}

Correspondence to: Mikhail V. Blagosklonny, email: blagosklonny@oncotarget.com

Keywords: $\mathrm{NCl}$, cancer, therapy, prevention, aging, rapamycin, mTOR

Received: December 8, 2011, Accepted: December 31, 2011, Published: December 31, 2011

Copyright: @ Blagosklonny. This is an open-access article distributed under the terms of the Creative Commons Attribution License, which permits unrestricted use, distribution, and reproduction in any medium, provided the original author and source are credited.

ABSTRACT:

\begin{abstract}
National Cancer Institute has announced 24 provocative questions on cancer. Here I try to answer some of them by linking the dots of existing knowledge.
\end{abstract}

\section{INTRODUCTION}

As announced by the NCI director Harold E. Varmus, answers to these perplexing questions will revolutionize prevention and treatment of cancer. How does obesity contribute to cancer risk? What is the mechanism by which some drugs commonly and chronically used for other indications protect against cancer? Can we use our knowledge of aging to enhance prevention or treatment of cancer? Can we develop methods to rapidly test interventions for cancer treatment or prevention? Why are some disseminated cancers cured by chemotherapy alone? Can we extend patient survival by using approaches that keep tumors static? Why do many cancer cells die when suddenly deprived of a protein encoded by an oncogene? http://provocativequestions.nci.nih.gov/?cid=WTq_cgov

What these questions have in common is that they cannot be answered by a single experiment. Knowledge from different fields needs to be brought together and seemingly unrelated facts to be linked. Then predictions can be tested by retrieving published data (virtual experiments) $[1,2]$. Here are answers to some questions. Since the order of questions was arbitrary, I have rearranged questions, keeping the original numbers.

PQ-22: Why do many cancer cells die when suddenly deprived of a protein encoded by an oncogene?

Oncogene addiction is dependence on oncogene, even though this oncogene was not needed before its activation [3-31]. For example, transfection of Bcr-Abl renders HL-60 cells apoptosis-reluctant, resistant to killing by most anti-cancer drugs [28, 32, 33]. In contrast, the Bcr-Abl inhibitor imatinib kills Bcr-Abl-transfected cells without affecting parental cells. Parental cells neither have Bcr-Abl nor need Bcr-Abl to start with. So why losing Bcr-Abl is detrimental but not having Bcr-Abl at all is not. Bcr-Abl inhibits apoptosis and therefore some other anti-apoptotic proteins become redundant. For example, while Bcl-2 is over expressed in HL-60 cells, it is not expressed in HL60/Bcr-Abl cells [34, 35]. (By the way, this also explains why Bcl-2 (and p53) status does not correlate with cell propensity to apoptosis (see [36-38]).

The Bcr-Abl addiction can be described by the dam model [39]. Bcr-Abl is 'a dam on the pro-apoptotic river'. Pro-apoptotic molecules accumulate upstream of the dam. For example, hyper-active caspase- 9 was detected in Bcr-Abl-expressing HL-60 cells [40]. When Bcr$\mathrm{Abl}$ is suddenly removed, then apoptotic signals "flow" downstream, causing a flood $[39,40]$.
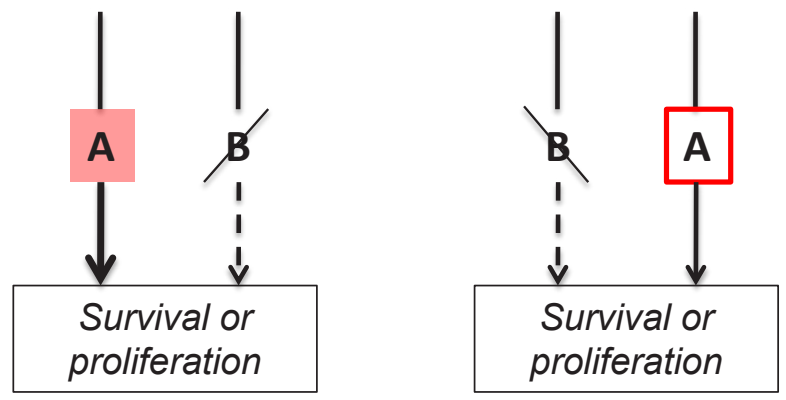

Figure 1: Oncogene addiction and synthetic lethality Oncogene addiction. Activation of pro-survival pathway A leads to deactivation of parallel (and redundant) pro-survival pathway B. Cell becomes addicted to "A". Targeting " $\mathrm{A}$ " will kill this cell.

Synthetic lethality. Loss of pro-survival pathway B renders the cell dependent on pro-survival pathway A. Targeting "A" will kill this cell. 
Let us make a generalization: Activation or overactivation of a pro-survival pathway may lead to deactivation of an alternative (and redundant) pro-survival pathway(s) because of redundancy (Figure 1, oncogene addiction).

Now we can connect two dots: Oncogene addiction (OA) and synthetic lethality (SL). Two genes are synthetic lethal if mutation of either alone is compatible with viability but mutation of both leads to death [19, 41-44]. At first glance, OA and SL are different phenomena. Yet, the difference between OA and SL is the sequence of events and ... our knowledge about these events.

In synthetic lethality, gene B (or process B) is inactivated first (Figure 1). This renders cell dependent on gene A (or process A). In oncogene addiction, gene $\mathrm{A}$ is overactivated first and gene $\mathrm{B}$ is inactivated later. Oncogene addiction (OA) is a mirror image of synthetic lethality (SL). The distinction between SL and OA depends on our knowledge of the sequence of events. When we introduce an oncogene, this is oncogene addiction. But what about natural oncogene-dependent tumors. Is that OA or SL? We cannot distinguish them. In other words, $\mathrm{OA}$ is SL and vice versa, depending on our point of view. For example, in OA gene A is known. In SL, we screen for gene A using agents that toxic to such cells. (Note: instead of gene, there might be a pathway or a process such as glycolysis, oxidative or protetoxic stress [45-47]. We use the word gene for brevity. )

In natural tumors, oncogene addiction is a consequence of selection for resistance to restrictive, growth-limiting conditions, when resistance is conferred by oncogene A. Definition: oncogenic resistance is resistance to cytostatic/cytotoxic agents based on oncogenic alterations such as loss of p53 or expression of Bcr-Abl, which renders cells both resistant and malignant [48]). But then the oncogenic cell may lose redundant pathway/gene $\mathrm{B}$, therefore becoming addicted to oncogene A. Thus, oncogene addiction (or synthetic lethality) and oncogenic resistance are two sides of the same coin.

\section{PQ-21: Given the appearance of resistance in response to cell killing therapies, can we extend survival by using approaches that keep tumors static?}

Will static drugs cause resistance? The answer is yes. Anything that is cytostatic must select for resistance. Sensitive cells get arrested, whereas rare resistant cells selectively proliferate. But this does not preclude successful therapy. Furthermore, selection for resistance is a consequence of successful treatment that keeps most cells static. In comparison, antibiotics (especially cytostatic agents) effectively select for resistance in bacteria. But still antibiotics are very useful. Compared with bacteria, mutation rates and cell numbers and mutation rate are relatively lower in cancer and resistant cancer cells do not spread to new patients (so acquired resistance always is acquired de novo).

While arresting sensitive cancer cells, static drugs select for resistant cancer cells. So therapy that effectively arrest tumor growth must select for resistance. Fortunately, any anticancer drugs including static drugs can select for resistance, only by causing therapeutic response due to arresting or killing non-resistant cells. Unfortunately, when resistance arises, resistant cancer cells tend to be more malignant and aggressive. This is because resistance can be oncogenic [48]. Therefore, therapeutic response often does not prolong life of cancer patient [49].

But here is a solution. In resistant tumors, we can select for drug sensitivity using antagonistic drug combinations [50]. Antagonistic combinations may be comprised of a toxic drug and a static drug that antagonizes (blocks) the toxic drug. If cells are (or become) resistant to the static drug, the toxic drug will kill them. Of course, the entire combination selects for resistance but this is resistance to the entire combination [50]. Yet resistance to the entire combination can be achieved by selection for sensitivity to the static drug. Such antagonistic combinations selectively eliminate resistant cancer cells in cell culture [51-56].

Furthermore, if normal cells are sensitive to a static drug but resistant cancer cells are not, then resistant cancer cells could be eliminated without toxic side effects. This links two dots: (a) prevention of resistance by antagonistic combinations and (b) protection of normal cells from chemotherapy. Normal cells can be protected from cell cycle-dependent chemotherapy by pre-treatment with cytostatic agents [56-62] and also by agents that block cell death selectively in normal cells [54, 63-68]. This strategy was discussed in detail [69-72]. Most importantly, drug combinations that selectively kill resistant cancer cells, while sparing normal cells, can be designed using currently available drugs $[62,71,73]$.

So will static drugs cause resistance? The answer is yes. But can they extend patient survival (despite appearance of resistance). The answer is also yes. Yes, if additional therapeutic modalities (such as antagonistic combinations and protection of normal cells) will be used in sequence [74].

\section{PQ-19: Why are some disseminated cancers cured by chemotherapy alone?}

Let us first discuss why most disseminated cancers are NOT cured by chemotherapy alone? First, common cancers such as lung, colorectal, breast, prostate, pancreatic, renal, thyroid cancers are age-related diseases, which occur late in life. During lifespan pre-malignant 
and malignant cells acquire mutations, undergo multiple rounds of selection and replication [75-80]. Cancer cells accumulate hundreds of mutations that render them oncogenic, abolishing cell death and cycle arrest [78, 8192]. Not surprisingly, they are also intrinsically resistant to chemotherapy. Furthermore, chemotherapy itself causes selection for resistance, which is associated with more malignant and aggressive phenotype and acceleration of tumor growth [49, 93, 94].

Second, these cancers arise from normal tissues resistant to therapy to start with. For example, side effects of chemotherapy are not prominent in breast and lung tissues compared with bone marrow. Why would breast and lung cancer be more sensitive to chemotherapy than bone marrow? Even further, apoptosis-avoidance is a hallmark of cancer, so these cancer cells must be even more resistant than their normal counterparts. Not surprisingly, therapeutic window is low. (Note: as we discussed, oncogenes confer resistance to some chemotherapy on the cost of oncogene addiction, which could be exploited for therapy).

Third, metastasis may require mutations beyond those required for primary tumors [82]. These additional oncogenic changes may contribute to resistance of disseminated cancers. For example, in pancreatic cancer, at least a decade separates the occurrence of the initiating mutation and the birth of the parental, non-metastatic founder cell. And at least five more years are required for the acquisition of metastatic ability and patients die an average of two years thereafter [95]. So cancer cells undergo long selection for fitness and oncogenic resistance $[80,96]$.

However, some cancers are highly sensitive to chemotherapy. Examples include testicular cancer, gestational choriocarcinoma, some lymphomas, childhood malignancies such as Wilms tumors. These cancers share three features.

1. Curable cancers arise from apoptosis-prone tissues such as lymphoid, testicular, embryonic and placental/ endometrial.

Apoptosis is a marker of therapeutic response and curable malignancies are prone to undergo apoptosis in response to therapy [97-105]. (Note: it has been emphasized that in most cancers apoptosis is not a predictive marker of therapeutic response [106-109]. Apoptosis is not important for therapy of such cancers, simply because these cancers are apoptosis-reluctant $[110,111]$. These are the same common cancers that are not curable by chemotherapy alone. One may suggest that these cancers are not curable exactly because apoptosis is not a primary response to chemotherapy or in other words because they are apoptosis-reluctant.

In contrast, curable disseminated cancers are apoptosis-prone. Testicular germ cell tumors are unique in their excellent response to DNA-damaging chemotherapy. Hypersensitivity of testicular tumors to etoposide-induced apoptosis is associated with functional p53 [112]. In cancer with overexpressed Mdm2, nutlin-3a induces p53 and apoptosis [113]. Similarly, testicular cancer easily undergo apoptosis in response to p53 induced by cisplatin. Resistance to cisplatin is linked to p53 mutation [114, 115]. Relapsed tumors are resistant to therapy [116].

2. Curable cancers arise without lengthy selection and progression. A few mutations may be sufficient for dissemination of these particular cancers (see feature 3 ) but they did not acquire resistance associated with tumor progression.

A peculiar example of cancer-like condition represents endometriosis, growth of normal endometrial cells, resembling malignant processes, including invasive growth and distant implantation. Oncogenic mutations are absent or very rare [117]. Medulloblastoma, the most common malignant brain tumor of children [118] has lower genetic alterations compared to adult solid tumors.

3. Curable disseminated cancers arise from tissues that "normally metastasize" (hematopoietic/lymphoid) and invasive (the placenta) and highly proliferative. So they can become disseminated with minimal number of mutations and without tumor-progression.

\section{PQ-17: Since current methods to assess potential cancer treatments are cumbersome, expensive, and often inaccurate, can we develop other methods to rapidly test interventions for cancer treatment or prevention?}

Although different cell culture methods can be suggested, they probably would share something in common: these rapid methods will be unaesthetic.

Currently, many methods are based on evenly plated cells in relatively low cell densities. In control, cells are beautifully healthy. It is easy to observe spectacular effects of drugs that induce apoptosis and senescence. However, almost everything in these methods is artificial. (the only correct parameters are temperature and $\mathrm{CO} 2$ levels. )

a. In the organism, cells exist in very high densities.

b. $21 \%$ oxygen used in cell culture does not exist in the body, only in the air. In tumors oxygen levels are 0. $1-3 \%$.

c. Cancer cells are usually cultured in high-glucose DME, with levels of glucose 5 fold higher than blood glucose levels.

d. In real tumors, levels of lactate are very high and $\mathrm{pH}$ is low.

Yet, hypoglycemic/hypoxic condition in vitro mimicking the tumor microenvironment markedly reduced the efficacy of anticancer drugs [119]. In the high cell density in hypoxia model, cancer cells lose viability due to self-poisoning with lactic acid. Some anti-cancer agents actually increase cell viability [120]. Overgrown, "yellow" cell cultures in hypoxic conditions may mimic in vivo 
environment.

\section{PQ-7: How does the lifespan of an organism affect the molecular mechanisms of cancer development, and can we use our deepening knowledge of aging to enhance prevention or treatment of cancer?}

What are cellular and molecular mechanisms linking aging and cancer? And what is cellular aging?

In proliferating normal cells, growth factors (GF) stimulate (a) cellular mass growth and metabolism and (b) cell cycle progression. Cellular mass growth is balanced by cell division. (Many signaling pathways that promote mass growth and metabolism converge on mTOR, so I will refer to them as the mTOR network or pathway). In the absence of growth signals, the cell neither grows nor cycles. This is quiescence $[121,122]$. When the cell cycle is blocked but mTOR is still active, then the arrested cell becomes senescent [122-134]. mTOR renders cells resistant to insulin and growth factors. As discussed in detail, senescent cells are hypertrophic, hyperfunctional, overactivated, pro-inflammatory and hypersecretory, signal-resistant and lack the regenerative potential (the inability to restart proliferation). Thus, mTOR converts quiescence into senescence. This process could be called gerogenic conversion or geroconversion [122]. Rapamycin slows down geroconversion. Rapamycin is a gerosuppressant.

Furthermore, mTOR is involved in cell senescence and stem cell exhaustion in the organism [135-140]. Also, rapamycin reverses cellular phenotypes in HutchinsonGilford progeria syndrome cells [141]. Whereas calorie restriction $(\mathrm{CR})$ deactivates the nutrient-sensing mTOR pathway [142], short-term CR suppresses cellular senescence in the organism [143, 144].

There are 3 links between aging and cancer that are in part mTOR-dependent.

First, senescent cells secrete pro-inflammatory factors [145-154]. Second, mTOR overactivation can cause insulin resistance [155-159], which in turn leads to a compensatory increase in insulin levels, which can promote cancer. Third, signal-resistance, irresponsiveness and loss of regenerative potential of the aging normal cells create a selective pressure to bypass the need for growth-signals and bypass cell cycle block. Unable to respond to physiological stimuli, normal cells are in disadvantage, unable to compete with premalignant cells. Cells with oncogenic mutations and loss of cell cycle control (due to mutations in p53, p16 and $\mathrm{Rb}$ ) selectively proliferate. In other words, due to irresponsiveness of aging normal cells to mitogenic signals and decreased regenerative potential of aging cells, there is a selective advantage for transformed cells, which are autonomous and lack cell cycle checkpoints. For example, declining lymphoid progenitor fitness promotes aging-associated leukemogenesis $[160,161]$. I suggest that restoration of signal-sensitivity and responsiveness of normal cells by pulse (intermittent) treatment with rapamycin can abolish selective advantage for cancer cells.

Thus, at least 3 mechanisms of how mTORdriven aging can contribute to cancer. This predicts that suppression of aging of normal cells by rapamycin will extend lifespan and delay cancer. In fact, numerous data support this prediction (see PQ-5). Noteworthy, rapamycin is not intended to directly affect cancer cells. It is intended to suppress geroconversion (suppress aging of normal cells). As a gerosuppressant, rapamycin will be used in low doses and in pulses, thus precluding side effects [162, 163].

In summary, the incidence of common cancers such as breast, prostate, colon, lung, pancreatic, gastric, bladder and certain leukemias is increased with age. Conditions that accelerate aging such as obesity also accelerate cancer, whereas slow aging is associated with delayed cancer. One can suggest that pharmacological interventions that slow down organismal aging will delay or prevent cancer. It was demonstrated that mTOR is involved in cellular senescence, converting quiescence into senescence (geroconversion). Importantly, mTOR is involved in organismal aging and its inhibition extends lifespan. Aging can be decelerated by rapamycin.

PQ-5: Given the evidence that some drugs commonly and chronically used for other indications, such as an anti-inflammatory drug, can protect against cancer incidence and mortality, can we determine the mechanism by which any of these drugs work?

Some drugs commonly and chronically used for other indications can protect against cancer. As announced by NCI, elucidating the mechanisms by which these agents work would be a major breakthrough in cancer prevention.

Preclinical and clinical data suggest that certain drugs used for diabetes, hypertension, atherosclerosis, inflammation and immunossupression can protect against cancer. These drugs include metformin, beta-blockers, angiotensin-blockers, aspirin and rapamycin. Since type II diabetes, hypertension, pro-inflammation and atherosclerosis are all age-related diseases and conditions, we can expect that these drugs may affect the aging process. And since cancer is also an age-related disease, conditions that slow down aging in turn delay or prevent cancer. At doses used in the clinic for treatment of agerelated diseases, these accidental cancer-preventive agents are relatively ineffective to treat cancer, implying that their cancer-preventive effects are not due to targeting cancer cells directly. Since the mTOR pathway is involved in cellular and organismal aging and age-related diseases, one can suggest that cancer preventive activities of 
"accidental" drugs are in part due to suppression of aging.

Rapamycin decelerates geroconversion (conversion of quiescence into senescence) in arrested cells [122-132]. Also rapamycin suppresses yeast aging and prolongs life span in Drosophila and mice [164-183].

Finally, rapamycin prevents cancer in mice [178, 179, 184-192] and humans [193-196]. Given that mTOR is the only one target of rapamycin, one can conclude that inhibition of mTOR is sufficient to suppress aging and delay cancer.

Metformin, an anti-diabetic drug, inhibits the mTOR pathway [197-200]. Metformin and its analog phenformin slow down aging, delay cancer and extend life span in rodents [201-210]. Also metformin decreases the risk of cancer in humans [206, 211-220].

Angiotensin-II-blockers. Inhibitors of angiotensin II activity include ACE inhibitors (such as captopril and lisinopril), which decrease angiotensin II production, and angiotensin receptor blockers such as losratan. Angiotensin-II-blockers suppress chemicallyinduced colon carcinogenesis in obese mice [221], hepatocarcinogenesis in rats [222] and metastasis in mice [222-224]. In humans, use of these drugs is associated with a lower incidence of cancer occurrence [225, 226]. In patients with renal transplantation, the use of angiotensinII-blockers is associated with a two-fold reduced risk of skin cancers [227].

Angiotensin-II activates mTOR pathway and causes

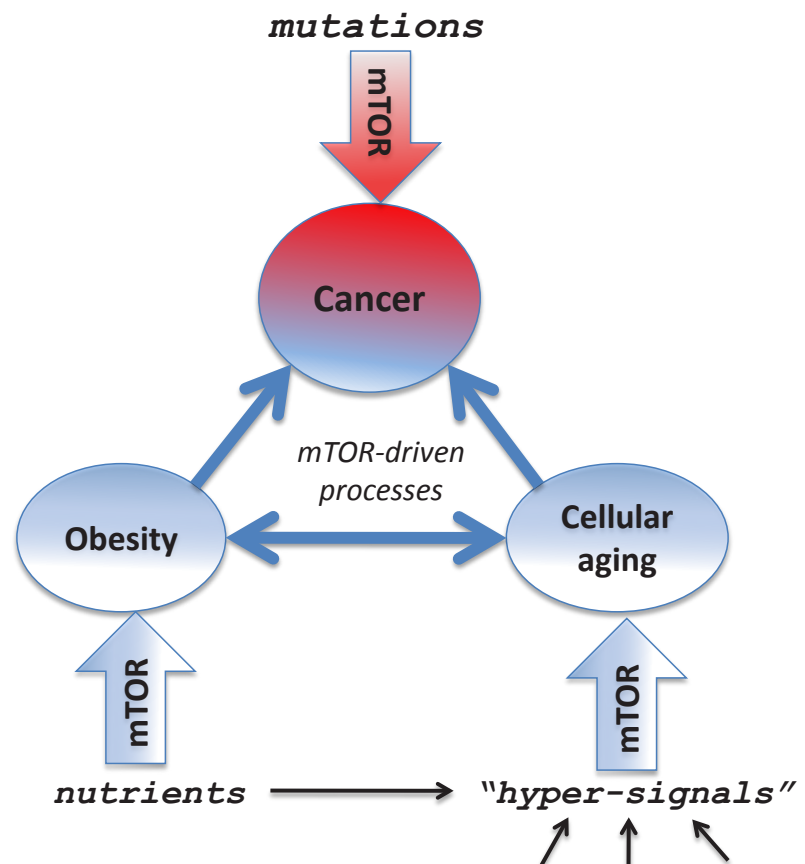

Figure 2: Several mTOR-dependent processes acting in concert can promote cancer. The mTOR pathway is involved in cellular and organismal aging, thus connecting aging to age-related diseases such as cancer. Pro-aging, growthpromoting and inflammatory pathways such as mTOR drive aging and cancer. Rapamycin may decrease cancer by (a) slowing aging, (b) preventing obesity and (c) directly affecting cancer cells. cellular hypertrophy [228-236]. Therefore, angiotensinII-blockers, which prevent these effects, are indirect inhibitors of mTOR.

Beta-blockers, which are used for therapy of hypertension, prevent breast cancer [237-242]. There are several publications that activators of beta-androgenic receptors can activate the mTOR pathway [243-245]. Therefore, beta-blockers are expected too block mTOR activation. This requires further investigations.

Aspirin decreases cancer incidence in humans [246-252]. As an anti-inflammatory agent, it decreases an important hallmark of aging. The effect of aspirin on gerogenic-signaling pathways such as mTOR needs to be studied in the organism. In some cell models, salicylate inhibits phosphorylation of S6, a downstream target of mTOR/S6K [253].

\section{PQ-1: How does obesity contribute to cancer risk?}

Summary: The simplest answer is that obesity promotes cancer by over-activating the nutrient-sensing mTOR pathway, which is involved in obesity, aging and cancer. Cancer is an age-related disease and accelerated aging promotes cancer. High-calorie diet and obesity activate mTOR, thus promoting aging and cancer. Rapamycin increases lifespan in mice including cancerprone mice and prevents cancer in part by slowing down aging. Given that rapamycin is a clinically approved drug, it can be used in low doses to prevent cancer in obese patients. Thus, one can suggest not only how obesity contributes to cancer risk but also a therapeutic strategy for cancer prevention.

\section{How obesity and cancer might be linked}

Many studies have documented an increased risk of cancer incidence and mortality in individuals who are obese [254-260]. What are mechanisms that underlie this risk? There are causative and correlative links between obesity and cancer.

Causative links: obesity promotes cancer

First, several factors secreted by the adipose tissue can directly stimulate tumor growth. Second, obesity causes hormonal changes such as insulinemia and insulin promotes cancer. Third, as we will discuss, obesity can accelerate aging and aging promotes cancer.

Correlative links: both obesity and cancer are promoted by a common cause

First, aging is a major risk factor for cancer and is associated with visceral obesity. Second, high-calorie diet can promote both obesity and cancer. Yet, even these correlative relationships are causative on a deeper level, sharing a common molecular mechanism that links aging, cancer and obesity. Thus, the same pathway (such as mTOR) may be involved in aging, obesity and cancer per se, as well as aging and obesity can mutually stimulate each other (via the mTOR pathway) and both of them 
play causative role in cancer (Figure 2). Pharmacological inhibition of such a common pathway will prevent or delay cancer. What are molecular changes induced by obesity that actually promote cancer development?

Dot 1. Nutrients and insulin activate mTOR, whereas calorie restriction (fasting) deactivates mTOR $[142,156$, 261-266].

Dot 2. The mTOR pathway promotes obesity and is activated in obesity [256, 261, 265, 268-272].

Dot 3. mTOR is involved in cellular aging [122132, 136-139, 273] and organismal aging [164-183]. Noteworthy, basal (fasting) levels of mTOR activity is increased in old mice [266].

Taken together (dots 1-3) these data predict that obesity would accelerate aging and age-related diseases, thus shortening life span. This prediction does not need to be tested. It is too well known that: Obesity accelerates all age-related diseases.

Dot 4. Obesity accelerates age-related diseases and shortens lifespan.

Dot 5. Cancer is age-related disease and accelerated aging accelerates cancer. Prediction 2. Since obesity accelerates aging and age-related diseases, obesity must accelerate cancer, which is an age-related disease. This prediction does not need to be tested. It is too well known that: Obesity increases cancer risk. Furthermore, this is exactly the starting point (PQ-1).

Prediction 3: Rapamycin should delay cancer by slowing down the aging process. In fact, rapamycin prevents cancer in mice $[178,184-192]$ and humans [193196].

Noteworthy, the activation PI3K/mTOR pathway by mutations (Figure 2) is one of the most universal alterations in cancer [87, 274-284].

As a gerosuppressant, rapamycin will be probably used in low doses and intermittent schedules to avoid side effects. It could be used for cancer prevention in obese patients with multiple age-related pathologies and could be combined with diet, physical exercise, aspirin, metformin, beta-blockers, angiotensin-blockers and lipid-lowering drugs. Then cancer can be delayed by staying young.

\section{FUNDING}

Roswell Park Cancer Institute, Buffalo, NY 14203.

\section{CONFLICTS OF INTERESTS}

No conflicts of interest to declare.

\section{REFERENCES}

1. Blagosklonny MV, Pardee AB. Conceptual biology: unearthing the gems. Nature. 2002; 416: 373.

2. Blagosklonny MV. Research by retrieving experiments.
Cell Cycle. 2007; 6: 1277-1283.

3. Weinstein IB, Begemann M, Zhou P, Han EK, Sgambato A, Doki Y, Arber N, Ciaparrone M, Yamamoto H. Disorders in cell circuitry associated with multistage carcinogenesis: exploitable targets for cancer prevention and therapy. Clin Cancer Res. 1997; 3: 2696-2702.

4. Weinstein IB. Cancer. Addiction to oncogenes--the Achilles heal of cancer. Science. 2002; 297: 63-64.

5. Weinstein IB, Joe A. Oncogene addiction. Cancer Res. 2008; 68: 3077-3080; discussion 3080.

6. Gazdar AF, Shigematsu H, Herz J, Minna JD. Mutations and addiction to EGFR: the Achilles 'heal' of lung cancers? Trends Mol Med. 2004; 10: 481-486.

7. Pao W, Miller V, Zakowski M, Doherty J, Politi K, Sarkaria I, Singh B, Heelan R, Rusch V, Fulton L, Mardis E, Kupfer D, Wilson R, Kris M, Varmus H. EGF receptor gene mutations are common in lung cancers from "never smokers" and are associated with sensitivity of tumors to gefitinib and erlotinib. Proc Natl Acad Sci U S A. 2004; 101: 13306-13311.

8. Fisher GH, Wellen SL, Klimstra D, Lenczowski JM, Tichelaar JW, Lizak MJ, Whitsett JA, Koretsky A, Varmus HE. Induction and apoptotic regression of lung adenocarcinomas by regulation of a K-Ras transgene in the presence and absence of tumor suppressor genes. Genes Dev. 2001; 15: 3249-3262.

9. Sharma SV, Gajowniczek P, Way IP, Lee DY, Jiang J, Yuza Y, Classon M, Haber DA, Settleman J. A common signaling cascade may underlie "addiction" to the Src, BCR-ABL, and EGF receptor oncogenes. Cancer Cell. 2006; 10: 425435 .

10. Politi K, Zakowski MF, Fan PD, Schonfeld EA, Pao W, Varmus HE. Lung adenocarcinomas induced in mice by mutant EGF receptors found in human lung cancers respond to a tyrosine kinase inhibitor or to down-regulation of the receptors. Genes Dev. 2006; 20: 1496-1510.

11. Sharma SV, Settleman J. Oncogenic shock: turning an activated kinase against the tumor cell. Cell Cycle. 2006; 5: 2878-2880.

12. Choo AY, Blenis J. TORgeting oncogene addiction for cancer therapy. Cancer Cell. 2006; 9: 77-79.

13. Sharma SV, Bell DW, Settleman J, Haber DA. Epidermal growth factor receptor mutations in lung cancer. Nat Rev Cancer. 2007; 7: 169-181.

14. Solimini NL, Luo J, Elledge SJ. Non-oncogene addiction and the stress phenotype of cancer cells. Cell. 2007; 130: 986-988.

15. Sharma SV, Settleman J. Oncogene addiction: setting the stage for molecularly targeted cancer therapy. Genes Dev. 2007; 21: 3214-3231.

16. Wu CH, van Riggelen J, Yetil A, Fan AC, Bachireddy $\mathrm{P}$, Felsher DW. Cellular senescence is an important mechanism of tumor regression upon c-Myc inactivation. Proc Natl Acad Sci U S A. 2007; 104: 13028-13033. 
17. Felsher DW. Oncogene addiction versus oncogene amnesia: perhaps more than just a bad habit? Cancer Res. 2008; 68: 3081-3086; discussion 3086.

18. Podsypanina K, Politi K, Beverly LJ, Varmus HE. Oncogene cooperation in tumor maintenance and tumor recurrence in mouse mammary tumors induced by Myc and mutant Kras. Proc Natl Acad Sci U S A. 2008; 105: $5242-$ 5247.

19. Bommi-Reddy A, Almeciga I, Sawyer J, Geisen C, Li W, Harlow E, Kaelin WG, Jr. , Grueneberg DA. Kinase requirements in human cells: III. Altered kinase requirements in VHL-/- cancer cells detected in a pilot synthetic lethal screen. Proc Natl Acad Sci U S A. 2008; 105: 16484-16489.

20. Dang CV. MYC, microRNAs and glutamine addiction in cancers. Cell Cycle. 2009; 8: 3243-3245.

21. Singh A, Settleman J. Oncogenic K-ras "addiction" and synthetic lethality. Cell Cycle. 2009; 8: 2676-2677.

22. Faber AC, Wong KK, Engelman JA. Differences underlying EGFR and HER2 oncogene addiction. Cell Cycle. 2010; 9: 851-852.

23. Lee JT, Shan J, Gu W. Targeting the degradation of cyclin D1 will help to eliminate oncogene addiction. Cell Cycle. 2010; 9: 857-858.

24. Demaria M, Giorgi C, Lebiedzinska M, Esposito G, D’Angeli L, Bartoli A, Gough DJ, Turkson J, Levy DE, Watson CJ, Wieckowski MR, Provero P, Pinton P, Poli V. A STAT3-mediated metabolic switch is involved in tumour transformation and STAT3 addiction. Aging (Albany NY). 2010; 2: 823-842.

25. Darnell JE, Jr. STAT3, HIF-1, glucose addiction and Warburg effect. Aging (Albany NY). 2010; 2: 890-891.

26. Jeang KT. Human T cell leukemia virus type 1 (HTLV-1) and oncogene or oncomiR addiction? Oncotarget. 2010; 1: 453-456.

27. Gualdrini F, Corvetta D, Cantilena S, Chayka O, Tanno B, Raschella G, Sala A. Addiction of MYCN amplified tumours to B-MYB underscores a reciprocal regulatory loop. Oncotarget. 2010; 1: 278-288.

28. Sawyers CL. Shifting paradigms: the seeds of oncogene addiction. Nat Med. 2009; 15: 1158-1161.

29. Luo J, Solimini NL, Elledge SJ. Principles of cancer therapy: oncogene and non-oncogene addiction. Cell. 2009; 136: 823-837.

30. Choi PS, van Riggelen J, Gentles AJ, Bachireddy P, Rakhra K, Adam SJ, Plevritis SK, Felsher DW. Lymphomas that recur after MYC suppression continue to exhibit oncogene addiction. Proc Natl Acad Sci U S A. 2011; 108: 1743217437.

31. Blagosklonny MV. Gefitinib (iressa) in oncogene-addictive cancers and therapy for common cancers. Cancer Biol Ther. 2004; 3: 436-440.

32. Druker BJ. Translation of the Philadelphia chromosome into therapy for CML. Blood. 2008; 112: 4808-4817.
33. Shah NP, Kasap C, Weier C, Balbas M, Nicoll JM, Bleickardt E, Nicaise C, Sawyers CL. Transient potent BCR-ABL inhibition is sufficient to commit chronic myeloid leukemia cells irreversibly to apoptosis. Cancer Cell. 2008; 14: 485-493.

34. Amarante-Mendes GP, Naekyung Kim C, Liu L, Huang Y, Perkins CL, Green DR, Bhalla K. Bcr-Abl exerts its antiapoptotic effect against diverse apoptotic stimuli through blockage of mitochondrial release of cytochrome C and activation of caspase-3. Blood. 1998; 91: 1700-1705.

35. Perkins C, Kim CN, Fang G, Bhalla KN. Arsenic induces apoptosis of multidrug-resistant human myeloid leukemia cells that express Bcr-Abl or overexpress MDR, MRP, Bcl2, or Bcl-x(L). Blood. 2000; 95: 1014-1022.

36. Blagosklonny MV. Paradox of Bcl-2 (and p53): why may apoptosis-regulating proteins be irrelevant to cell death? Bioessays. 2001; 23: 947-953.

37. Gurova KV, Kwek SS, Koman IE, Komarov AP, Kandel E, Nikiforov MA, Gudkov AV. Apoptosis inhibitor as a suppressor of tumor progression: expression of $\mathrm{Bcl}-2$ eliminates selective advantages for p53-deficient cells in the tumor. Cancer Biol Ther. 2002; 1: 39-44.

38. Gurova KV, Gudkov AV. Paradoxical role of apoptosis in tumor progression. J Cell Biochem. 2003; 88: 128-137.

39. Blagosklonny MV. Do cells need CDK2 and... Bcr-Abl? Cell Death Differ. 2004; 11: 249-251.

40. Demidenko ZN, An WG, Lee JT, Romanova LY, McCubrey JA, Blagosklonny MV. Kinase-addiction and bi-phasic sensitivity-resistance of Bcr-Abl- and Raf-1expressing cells to imatinib and geldanamycin. Cancer Biol Ther. 2005; 4: 484-490.

41. Kaelin WG, Jr. The concept of synthetic lethality in the context of anticancer therapy. Nat Rev Cancer. 2005; 5: 689-698.

42. Rehman FL, Lord CJ, Ashworth A. Synthetic lethal approaches to breast cancer therapy. Nat Rev Clin Oncol. 2010; 7: 718-724.

43. Bauzon F, Zhu L. Racing to block tumorigenesis after pRb loss: an innocuous point mutation wins with synthetic lethality. Cell Cycle. 2010; 9: 2118-2123.

44. Reinhardt HC, Jiang H, Hemann MT, Yaffe MB. Exploiting synthetic lethal interactions for targeted cancer therapy. Cell Cycle. 2009; 8: 3112-3119.

45. Shaw AT, Winslow MM, Magendantz M, Ouyang C, Dowdle J, Subramanian A, Lewis TA, Maglathin RL, Tolliday N, Jacks T. Selective killing of K-ras mutant cancer cells by small molecule inducers of oxidative stress. Proc Natl Acad Sci U S A. 2011; 108: 8773-8778.

46. Neznanov N, Gorbachev AV, Neznanova L, Komarov AP, Gurova KV, Gasparian AV, Banerjee AK, Almasan A, Fairchild RL, Gudkov AV. Anti-malaria drug blocks proteotoxic stress response: anti-cancer implications. Cell Cycle. 2009; 8: 3960-3970.

47. Neznanov N, Komarov AP, Neznanova L, Stanhope-Baker 
P, Gudkov AV. Proteotoxic stress targeted therapy (PSTT): induction of protein misfolding enhances the antitumor effect of the proteasome inhibitor bortezomib. Oncotarget. 2011; 2: 209-221.

48. Blagosklonny MV. Oncogenic resistance to growth-limiting conditions. Nat Rev Cancer. 2002; 2: 221-225.

49. Blagosklonny MV. Why therapeutic response may not prolong the life of a cancer patient: selection for oncogenic resistance. Cell Cycle. 2005; 4: 1693-1698.

50. Blagosklonny MV. Antagonistic drug combinations that select against drug resistance: from bacteria to cancer. Cancer Biol Ther. 2007; 6: 1013-1014.

51. Blagosklonny MV. Drug-resistance enables selective killing of resistant leukemia cells: exploiting of drug resistance instead of reversal. Leukemia. 1999; 13: 2031-2035.

52. Blagosklonny MV, Bishop PC, Robey R, Fojo T, Bates SE. Loss of cell cycle control allows selective microtubuleactive drug-induced Bcl-2 phosphorylation and cytotoxicity in autonomous cancer cells. Cancer Res. 2000; 60: 34253428.

53. Blagosklonny MV, Robey R, Bates S, Fojo T. Pretreatment with DNA-damaging agents permits selective killing of checkpoint-deficient cells by microtubule-active drugs. J Clin Invest. 2000; 105: 533-539.

54. Blagosklonny MV. Treatment with inhibitors of caspases, that are substrates of drug transporters, selectively permits chemotherapy-induced apoptosis in multidrug-resistant cells but protects normal cells. Leukemia. 2001; 15: 936941.

55. Blagosklonny MV. Sequential activation and inactivation of $\mathrm{G} 2$ checkpoints for selective killing of p53-deficient cells by microtubule-active drugs. Oncogene. 2002; 21: 62496254.

56. Demidenko ZN, Halicka D, Kunicki J, McCubrey JA, Darzynkiewicz Z, Blagosklonny MV. Selective killing of adriamycin-resistant (G2 checkpoint-deficient and MRP1expressing) cancer cells by docetaxel. Cancer Res. 2005; 65: 4401-4407.

57. Carvajal D, Tovar C, Yang H, Vu BT, Heimbrook DC, Vassilev LT. Activation of p53 by MDM2 antagonists can protect proliferating cells from mitotic inhibitors. Cancer Res. 2005; 65: 1918-1924.

58. Sur S, Pagliarini R, Bunz F, Rago C, Diaz LA, Jr. , Kinzler KW, Vogelstein B, Papadopoulos N. A panel of isogenic human cancer cells suggests a therapeutic approach for cancers with inactivated p53. Proc Natl Acad Sci U S A. 2009; 106: 3964-3969.

59. Choong ML, Yang H, Lee MA, Lane DP. Specific activation of the p53 pathway by low dose actinomycin D: a new route to 553 based cyclotherapy. Cell Cycle. 2009; 8: 2810-2818.

60. Cheok CF, Kua N, Kaldis P, Lane DP. Combination of nutlin-3 and VX-680 selectively targets p53 mutant cells with reversible effects on cells expressing wild-type p53.
Cell Death Differ. 2010; 17: 1486-1500.

61. Rao B, van Leeuwen IM, Higgins M, Campbel J, Thompson AM, Lane DP, Lain S. Evaluation of an Actinomycin D/ VX-680 aurora kinase inhibitor combination in p53-based cyclotherapy. Oncotarget. 2010; 1: 639-650.

62. Apontes P, Leontieva OV, Demidenko ZN, Li F, Blagosklonny MV. Exploring long-term protection of normal human fibroblasts and epithelial cells from chemotherapy in cell culture. Oncotarget. 2011; 2: 222-233.

63. Komarov PG, Komarova EA, Kondratov RV, ChristovTselkov K, Coon JS, Chernov MV, Gudkov AV. A chemical inhibitor of $\mathrm{p} 53$ that protects mice from the side effects of cancer therapy. Science. 1999; 285: 1733-1737.

64. Komarova EA, Gudkov AV. Chemoprotection from p53dependent apoptosis: potential clinical applications of the p53 inhibitors. Biochem Pharmacol. 2001; 62: 657-667.

65. Blagosklonny MV. Targeting cancer cells by exploiting their resistance. Trends Mol Med. 2003; 9: 307-312.

66. Strom E, Sathe S, Komarov PG, Chernova OB, Pavlovska I, Shyshynova I, Bosykh DA, Burdelya LG, Macklis RM, Skaliter R, Komarova EA, Gudkov AV. Small-molecule inhibitor of $\mathrm{p} 53$ binding to mitochondria protects mice from gamma radiation. Nat Chem Biol. 2006; 2: 474-479.

67. Burdelya LG, Krivokrysenko VI, Tallant TC, Strom E, Gleiberman AS, Gupta D, Kurnasov OV, Fort FL, Osterman AL, Didonato JA, Feinstein E, Gudkov AV. An agonist of toll-like receptor 5 has radioprotective activity in mouse and primate models. Science. 2008; 320: 226-230.

68. Burdelya LG, Gleiberman AS, Toshkov I, Aygun-Sunar S, Bapardekar M, Manderscheid-Kern P, Bellnier D, Krivokrysenko VI, Feinstein E, Gudkov AV. Toll-like Receptor 5 Agonist Protects Mice from Dermatitis and Oral Mucositis Caused by Local Radiation: Implications for Head-and-Neck Cancer Radiotherapy. Int J Radiat Oncol Biol Phys. 2011.

69. Blagosklonny MV, Pardee AB. Exploiting cancer cell cycling for selective protection of normal cells. Cancer Res. 2001; 61: 4301-4305.

70. Blagosklonny MV, Darzynkiewicz Z. Cyclotherapy: protection of normal cells and unshielding of cancer cells. Cell Cycle. 2002; 1: 375-382.

71. Blagosklonny MV. "Targeting the absence" and therapeutic engineering for cancer therapy. Cell Cycle. 2008; 7: 13071312.

72. Gudkov AV, Komarova EA. Radioprotection: smart games with death. J Clin Invest. 2010; 120: 2270-2273.

73. Safdie FM, Dorff T, Quinn D, Fontana L, Wei M, Lee C, Cohen P, Longo VD. Fasting and cancer treatment in humans: A case series report. Aging (Albany NY). 2009; 1: 988-1007.

74. Blagosklonny MV. How cancer could be cured by 2015 . Cell Cycle. 2005; 4: 269-278.

75. Komarova NL, Lengauer C, Vogelstein B, Nowak MA. Dynamics of genetic instability in sporadic and familial 
colorectal cancer. Cancer Biol Ther. 2002; 1: 685-692.

76. Lengauer C, Kinzler KW, Vogelstein B. Genetic instabilities in human cancers. Nature. 1998; 396: 643-649.

77. Cahill DP, Kinzler KW, Vogelstein B, Lengauer C. Genetic instability and darwinian selection in tumours. Trends Cell Biol. 1999; 9: M57-60.

78. Vogelstein B, Kinzler KW. Cancer genes and the pathways they control. Nat Med. 2004; 10: 789-799.

79. Bozic I, Antal T, Ohtsuki H, Carter H, Kim D, Chen S, Karchin R, Kinzler KW, Vogelstein B, Nowak MA. Accumulation of driver and passenger mutations during tumor progression. Proc Natl Acad Sci U S A. 2010; 107: 18545-18550.

80. Valastyan S, Weinberg RA. Tumor metastasis: molecular insights and evolving paradigms. Cell. 2011; 147: 275-292.

81. Beerenwinkel N, Antal T, Dingli D, Traulsen A, Kinzler KW, Velculescu VE, Vogelstein B, Nowak MA. Genetic progression and the waiting time to cancer. PLoS Comput Biol. 2007; 3: e225.

82. Campbell PJ, Yachida S, Mudie LJ, Stephens PJ, Pleasance ED, Stebbings LA, Morsberger LA, Latimer C, McLaren S, Lin ML, McBride DJ, Varela I, Nik-Zainal SA, Leroy C, Jia M, Menzies A et al. The patterns and dynamics of genomic instability in metastatic pancreatic cancer. Nature. 2010; 467: 1109-1113.

83. Carter H, Chen S, Isik L, Tyekucheva S, Velculescu VE, Kinzler KW, Vogelstein B, Karchin R. Cancerspecific high-throughput annotation of somatic mutations: computational prediction of driver missense mutations. Cancer Res. 2009; 69: 6660-6667.

84. Wood LD, Parsons DW, Jones S, Lin J, Sjoblom T, Leary RJ, Shen D, Boca SM, Barber T, Ptak J, Silliman N, Szabo S, Dezso Z, Ustyanksky V, Nikolskaya T, Nikolsky Y et al. The genomic landscapes of human breast and colorectal cancers. Science. 2007; 318: 1108-1113.

85. Gupta A, Yang Q, Pandita RK, Hunt CR, Xiang T, Misri S, Zeng S, Pagan J, Jeffery J, Puc J, Kumar R, Feng Z, Powell SN, Bhat A, Yaguchi T, Wadhwa R et al. Cell cycle checkpoint defects contribute to genomic instability in PTEN deficient cells independent of DNA DSB repair. Cell Cycle. 2009; 8: 2198-2210.

86. Jacks T, Weinberg RA. Taking the study of cancer cell survival to a new dimension. Cell. 2002; 111: 923-925.

87. Parsons DW, Wang TL, Samuels Y, Bardelli A, Cummins JM, DeLong L, Silliman N, Ptak J, Szabo S, Willson JK, Markowitz S, Kinzler KW, Vogelstein B, Lengauer C, Velculescu VE. Colorectal cancer: mutations in a signalling pathway. Nature. 2005; 436: 792.

88. Serrano M, Gomez-Lahoz E, DePinho RA, Beach D, BarSagi D. Inhibition of ras-induced proliferation and cellular transformation by p16INK4. Science. 1995; 267: 249-252.

89. Xue C, Haber M, Flemming C, Marshall GM, Lock RB, MacKenzie KL, Gurova KV, Norris MD, Gudkov AV. p53 determines multidrug sensitivity of childhood neuroblastoma. Cancer Res. 2007; 67: 10351-10360.

90. Ventura A, Kirsch DG, McLaughlin ME, Tuveson DA, Grimm J, Lintault L, Newman J, Reczek EE, Weissleder $\mathrm{R}$, Jacks T. Restoration of p53 function leads to tumour regression in vivo. Nature. 2007; 445: 661-665.

91. Young NP, Crowley D, Jacks T. Uncoupling cancer mutations reveals critical timing of p53 loss in sarcomagenesis. Cancer Res. 2011; 71: 4040-4047.

92. Hanahan D, Weinberg RA. Hallmarks of cancer: the next generation. Cell. 2011; 144: 646-674.

93. Blagosklonny MV. Antiangiogenic therapy and tumor progression. Cancer Cell. 2004; 5: 13-17.

94. Oliver TG, Mercer KL, Sayles LC, Burke JR, Mendus D, Lovejoy KS, Cheng MH, Subramanian A, Mu D, Powers S, Crowley D, Bronson RT, Whittaker CA, Bhutkar A, Lippard SJ, Golub T et al. Chronic cisplatin treatment promotes enhanced damage repair and tumor progression in a mouse model of lung cancer. Genes Dev. 2010; 24: 837-852.

95. Yachida S, Jones S, Bozic I, Antal T, Leary R, Fu B, Kamiyama M, Hruban RH, Eshleman JR, Nowak MA, Velculescu VE, Kinzler KW, Vogelstein B, IacobuzioDonahue CA. Distant metastasis occurs late during the genetic evolution of pancreatic cancer. Nature. 2010; 467: 1114-1117.

96. Gupta GP, Massague J. Cancer metastasis: building a framework. Cell. 2006; 127: 679-695.

97. Fisher DE. Apoptosis in cancer therapy: crossing the threshold. Cell. 1994; 78: 539-542.

98. Martin SJ, Green DR. Apoptosis as a goal of cancer therapy. Curr Opin Oncol. 1994; 6: 616-621.

99. Houghton JA. Apoptosis and drug response. Curr Opin Oncol. 1999; 11: 475-481.

100. Reed JC. Dysregulation of apoptosis in cancer. J Clin Oncol. 1999; 17: 2941-2953.

101. Reed JC. Mechanisms of apoptosis avoidance in cancer. Curr Opin Oncol. 1999; 11: 68-75.

102. Sellers WR, Fisher DE. Apoptosis and cancer drug targeting. J Clin Invest. 1999; 104: 1655-1661.

103. Kolenko V, Uzzo RG, Bukowski R, Bander NH, Novick AC, Hsi ED, Finke JH. Dead or dying: Necrosis versus apoptosis in caspase-deficient human renal cell carcinoma. Cancer Res. 1999; 59: 2838-2842.

104. Lowe SW, Lin AW. Apoptosis in cancer. Carcinogenesis. 2000; 21: 485-495.

105. Johnstone RW, Ruefli AA, Lowe SW. Apoptosis: a link between cancer genetics and chemotherapy. Cell. 2002; 108: 153-164.

106. Brown JM, Wilson G. Apoptosis genes and resistance to cancer therapy: what does the experimental and clinical data tell us? Cancer Biol Ther. 2003; 2: 477-490.

107. Roninson IB, Broude EV, Chang BD. If not apoptosis, then what? Treatment-induced senescence and mitotic 
catastrophe in tumor cells. Drug Resist Updat. 2001; 4: $303-$ 313.

108. Roninson IB. Tumor senescence as a determinant of drug response in vivo. Drug Resist Updat. 2002; 5: 204-208.

109. Okada H, Mak TW. Pathways of apoptotic and nonapoptotic death in tumour cells. Nat Rev Cancer. 2004; 4: 592-603.

110. Blagosklonny MV. Cell death beyond apoptosis. Leukemia. 2000; 14: 1502-1508.

111. Blagosklonny MV, Robey R, Sheikh MS, Fojo T. Paclitaxel-induced FasL-independent apoptosis and slow (non-apoptotic) cell death. Cancer Biol Ther. 2002; 1: 113117.

112. Chresta CM, Masters JR, Hickman JA. Hypersensitivity of human testicular tumors to etoposide-induced apoptosis is associated with functional p53 and a high Bax:Bcl-2 ratio. Cancer Res. 1996; 56: 1834-1841.

113. Li B, Cheng Q, Li Z, Chen J. p53 inactivation by MDM2 and MDMX negative feedback loops in testicular germ cell tumors. Cell Cycle. 2010; 9: 1411-1420.

114. Houldsworth J, Xiao H, Murty VV, Chen W, Ray B, Reuter VE, Bosl GJ, Chaganti RS. Human male germ cell tumor resistance to cisplatin is linked to TP53 gene mutation. Oncogene. 1998; 16: 2345-2349.

115. Gutekunst M, Oren M, Weilbacher A, Dengler MA, Markwardt C, Thomale J, Aulitzky WE, van der Kuip H. p53 hypersensitivity is the predominant mechanism of the unique responsiveness of testicular germ cell tumor (TGCT) cells to cisplatin. PLoS One. 2011; 6: e19198.

116. Ehrlich Y, Baniel J. Late relapse of testis cancer. Urol Clin North Am. 2007; 34: 253-258; abstract x-xi.

117. Vestergaard AL, Thorup K, Knudsen UB, Munk T, Rosbach H, Poulsen JB, Guldberg P, Martensen PM. Oncogenic events associated with endometrial and ovarian cancers are rare in endometriosis. Mol Hum Reprod. 2011; 17: 758-761.

118. Parsons DW, Li M, Zhang X, Jones S, Leary RJ, Lin JC, Boca SM, Carter H, Samayoa J, Bettegowda C, Gallia GL, Jallo GI, Binder ZA, Nikolsky Y, Hartigan J, Smith DR et al. The genetic landscape of the childhood cancer medulloblastoma. Science. 2011; 331: 435-439.

119. Onozuka H, Tsuchihara K, Esumi H. Hypoglycemic/ hypoxic condition in vitro mimicking the tumor microenvironment markedly reduced the efficacy of anticancer drugs. Cancer Sci. 2011; 102: 975-982.

120. Leontieva OV, Blagosklonny MV. Yeast-like chronological senescence in mammalian cells: phenomenon, mechanism and pharmacological suppression. Aging (Albany NY). 2011; 3: 1078-1091.

121. Blagosklonny MV. Cell senescence and hypermitogenic arrest. EMBO Rep. 2003; 4: 358-362.

122. Blagosklonny MV. Cell cycle arrest is not senescence. Aging (Albany NY). 2011; 3: 94-101.

123. Demidenko ZN, Blagosklonny MV. Growth stimulation leads to cellular senescence when the cell cycle is blocked.
Cell Cycle. 2008; 7: 3355-3361.

124. Demidenko ZN, Zubova SG, Bukreeva EI, Pospelov VA, Pospelova TV, Blagosklonny MV. Rapamycin decelerates cellular senescence. Cell Cycle. 2009; 8: 1888-1895.

125. Demidenko ZN, Shtutman M, Blagosklonny MV. Pharmacologic inhibition of MEK and PI-3K converges on the mTOR/S6 pathway to decelerate cellular senescence. Cell Cycle. 2009; 8: 1896-1900.

126. Demidenko ZN, Blagosklonny MV. Quantifying pharmacologic suppression of cellular senescence: prevention of cellular hypertrophy versus preservation of proliferative potential. Aging (Albany NY). 2009; 1: 10081016.

127. Pospelova TV, Demidenk ZN, Bukreeva EI, Pospelov VA, Gudkov AV, Blagosklonny MV. Pseudo-DNA damage response in senescent cells. Cell Cycle. 2009; 8: 4112-4118.

128. Demidenko ZN, Korotchkina LG, Gudkov AV, Blagosklonny MV. Paradoxical suppression of cellular senescence by p53. Proc Natl Acad Sci U S A. 2010; 107: 9660-9664.

129. Korotchkina LG, Leontieva OV, Bukreeva EI, Demidenko ZN, Gudkov AV, Blagosklonny MV. The choice between p53-induced senescence and quiescence is determined in part by the mTOR pathway. Aging (Albany NY). 2010; 2: 344-352.

130. Leontieva OV, Blagosklonny MV. DNA damaging agents and p53 do not cause senescence in quiescent cells, while consecutive re-activation of mTOR is associated with conversion to senescence. Aging (Albany NY). 2010; 2: 924-935.

131. Leontieva O, Gudkov A, Blagosklonny M. Weak p53 permits senescence during cell cycle arrest. Cell Cycle. 2010; 9: 4323-4327.

132. Blagosklonny MV. Aging-suppressants: cellular senescence (hyperactivation) and its pharmacologic deceleration. Cell Cycle. 2009; 8: 1883-1887.

133. Wesierska-Gadek J. mTOR and its link to the picture of Dorian Gray - re-activation of mTOR promotes aging. Aging (Albany NY). 2010; 2: 892-893.

134. Galluzzi L, Kepp O, Kroemer G. TP53 and MTOR crosstalk to regulate cellular senescence. Aging (Albany NY). 2010; 2: 535-537.

135. Blagosklonny MV. Aging, stem cells, and mammalian target of rapamycin: a prospect of pharmacologic rejuvenation of aging stem cells. Rejuvenation Res. 2008; 11: 801-808.

136. Chen C, Liu Y, Zheng P. mTOR regulation and therapeutic rejuvenation of aging hematopoietic stem cells. Sci Signal. 2009; 2: ra75.

137. Gan B, Sahin E, Jiang S, Sanchez-Aguilera A, Scott KL, Chin L, Williams DA, Kwiatkowski DJ, DePinho RA. mTORC1-dependent and -independent regulation of stem cell renewal, differentiation, and mobilization. Proc Natl Acad Sci U S A. 2008; 105: 19384-19389.

138. Gan B, DePinho RA. mTORC1 signaling governs 
hematopoietic stem cell quiescence. Cell Cycle. 2009; 8: 1003-1006.

139. Castilho RM, Squarize CH, Chodosh LA, Williams BO, Gutkind JS. mTOR mediates Wnt-induced epidermal stem cell exhaustion and aging. Cell Stem Cell. 2009; 5: 279289.

140. Wang CY, Kim HH, Hiroi Y, Sawada N, Salomone S, Benjamin LE, Walsh K, Moskowitz MA, Liao JK. Obesity increases vascular senescence and susceptibility to ischemic injury through chronic activation of Akt and mTOR. Sci Signal. 2009; 2: ra11.

141. Cao K, Graziotto JJ, Blair CD, Mazzulli JR, Erdos MR, Krainc D, Collins FS. Rapamycin reverses cellular phenotypes and enhances mutant protein clearance in Hutchinson-Gilford progeria syndrome cells. Sci Transl Med. 2011; 3: 89ra58.

142. Blagosklonny MV. Calorie restriction: Decelerating mTORdriven aging from cells to organisms (including humans). Cell Cycle. 2010; 9: 683-688.

143. Wang C, Maddick M, Miwa S, Jurk D, Czapiewski R, Saretzki G, Langie SA, Godschalk RW, Cameron K, von Zglinicki T. Adult-onset, short-term dietary restriction reduces cell senescence in mice. Aging (Albany NY). 2010; 2: $555-566$.

144. Kirkland JL. Perspectives on cellular senescence and short term dietary restriction in adults. Aging (Albany NY). 2010; 2: $542-544$.

145. CoppŽ JP, Patil CK, Rodier F, Sun Y, Mu-oz DP, Goldstein J, Nelson PS, Desprez PY, Campisi J. Senescenceassociated secretory phenotypes reveal cell-nonautonomous functions of oncogenic RAS and the p53 tumor suppressor. PLoS Biol. 2008; 6: 2853-2868.

146. Krtolica A, Parrinello S, Lockett S, Desprez PY, Campisi J. Senescent fibroblasts promote epithelial cell growth and tumorigenesis: a link between cancer and aging. Proc Natl Acad Sci U S A. 2001; 98: 12072-12077.

147. Bhaumik D, Scott GK, Schokrpur S, Patil CK, Orjalo AV, Rodier F, Lithgow GJ, Campisi J. MicroRNAs miR$146 \mathrm{a} / \mathrm{b}$ negatively modulate the senescence-associated inflammatory mediators IL-6 and IL-8. Aging (Albany NY). 2009; 1: 402-411.

148. Rodier F, Coppe JP, Patil CK, Hoeijmakers WA, Munoz DP, Raza SR, Freund A, Campeau E, Davalos AR, Campisi J. Persistent DNA damage signalling triggers senescenceassociated inflammatory cytokine secretion. Nat Cell Biol. 2009; 11: 973-979.

149. Rodier F, Munoz DP, Teachenor R, Chu V, Le O, Bhaumik D, Coppe JP, Campeau E, Beausejour CM, Kim SH, Davalos AR, Campisi J. DNA-SCARS: distinct nuclear structures that sustain damage-induced senescence growth arrest and inflammatory cytokine secretion. J Cell Sci. 2011; 124: 68-81.

150. Komarova EA, Krivokrysenko V, Wang K, Neznanov N, Chernov MV, Komarov PG, Brennan ML, Golovkina
TV, Rokhlin OW, Kuprash DV, Nedospasov SA, Hazen SL, Feinstein E, Gudkov AV. p53 is a suppressor of inflammatory response in mice. Faseb J. 2005; 19: 10301032.

151. Ye J, Keller JN. Regulation of energy metabolism by inflammation: a feedback response in obesity and calorie restriction. Aging (Albany NY). 2010; 2: 361-368.

152. Lewis DA, Travers JB, Machado C, Somani AK, Spandau DF. Reversing the aging stromal phenotype prevents carcinoma initiation. Aging (Albany NY). 2011; 3: 407416.

153. Pani G. From growing to secreting: new roles for mTOR in aging cells. Cell Cycle. 2011; 10: 2450-2453.

154. Lisanti MP, Martinez-Outschoorn UE, Pavlides S, Whitaker-Menezes D, Pestell RG, Howell A, Sotgia F. Accelerated aging in the tumor microenvironment: connecting aging, inflammation and cancer metabolism with personalized medicine. Cell Cycle. 2011; 10: 20592063.

155. Shah OJ, Wang Z, Hunter T. Inappropriate activation of the TSC/Rheb/mTOR/S6K cassette induces IRS1/2 depletion, insulin resistance, and cell survival deficiencies. Curr Biol. 2004; 14: 1650-1656.

156. Tremblay F, Krebs M, Dombrowski L, Brehm A, Bernroider E, Roth E, Nowotny P, WaldhŠusl W, Marette A, Roden M. Overactivation of S6 kinase 1 as a cause of human insulin resistance during increased amino acid availability. Diabetes. 2005; 54: 2674-2684.

157. Krebs M, Brunmair B, Brehm A, Artwohl M, Szendroedi J, Nowotny P, Roth E, FŸrnsinn C, Promintzer M, Anderwald C, Bischof M, Roden M. The Mammalian target of rapamycin pathway regulates nutrient-sensitive glucose uptake in man. Diabetes. 2007; 56: 1600-1607.

158. Mordier S, Iynedjian PB. Activation of mammalian target of rapamycin complex 1 and insulin resistance induced by palmitate in hepatocytes. Biochem Biophys Res Commun. 2007; 362: 206-211.

159. Blagosklonny MV. Rapamycin-induced glucose intolerance: Hunger or starvation diabetes. Cell Cycle. 2011; 10: 42174224.

160. Henry CJ, Marusyk A, Zaberezhnyy V, Adane B, DeGregori J. Declining lymphoid progenitor fitness promotes agingassociated leukemogenesis. Proc Natl Acad Sci U S A. 2010; 107: 21713-21718.

161. Henry CJ, Marusyk A, DeGregori J. Aging-associated changes in hematopoiesis and leukemogenesis: what's the connection? Aging (Albany NY). 2011; 3: 643-656.

162. Blagosklonny MV. Validation of anti-aging drugs by treating age-related diseases. Aging (Albany NY). 2009; 1 : 281-288.

163. Blagosklonny MV. Increasing healthy lifespan by suppressing aging in our lifetime: Preliminary proposal. Cell Cycle. 2010; 9: 4788-4794.

164. Vellai T, Takacs-Vellai K, Zhang Y, Kovacs AL, Orosz L, 
Muller F. Genetics: influence of TOR kinase on lifespan in C. elegans. Nature. 2003; 426: 620.

165. Powers RWr, Kaeberlein M, Caldwell SD, Kennedy BK, Fields S. Extension of chronological life span in yeast by decreased TOR pathway signaling. Genes Dev. 2006; 20: 174-184.

166. Kaeberlein M, Powers RWr, K. K. S, Westman EA, Hu D, Dang N, Kerr EO, Kirkland KT, Fields S, Kennedy BK. Regulation of yeast replicative life span by TOR and Sch9 in response to nutrients. Science. 2005; 310: 1193-1196.

167. Jia K, Chen D, Riddle DL. The TOR pathway interacts with the insulin signaling pathway to regulate $\mathrm{C}$. elegans larval development, metabolism and life span. Development. 2004; 131: 3897-3906.

168. Kapahi P, Zid BM, Harper T, Koslover D, Sapin V, Benzer S. Regulation of lifespan in Drosophila by modulation of genes in the TOR signaling pathway. Curr Biol. 2004; 14: 885-890.

169. Pan Y, Shadel GS. Extension of chronological life span by reduced TOR signaling requires down-regulation of Sch9p and involves increased mitochondrial OXPHOS complex density. Aging (Albany NY). 2009; 1: 131-145.

170. Harrison DE, Strong R, Sharp ZD, Nelson JF, Astle CM, Flurkey K, Nadon NL, Wilkinson JE, Frenkel K, Carter CS, Pahor M, Javors MA, Fernandezr E, Miller RA. Rapamycin fed late in life extends lifespan in genetically heterogenous mice. Nature. 2009; 460: 392-396.

171. Honjoh S, Yamamoto T, Uno M, Nishida E. Signalling through RHEB-1 mediates intermittent fasting-induced longevity in C. elegans. Nature. 2009; 457: 726-730.

172. Masternak MM, Panici JA, Bonkowski MS, Hughes LF, Bartke A. Insulin sensitivity as a key mediator of growth hormone actions on longevity. J Gerontol A Biol Sci Med Sci. 2009; 64: 516-521.

173. Estep PWr, Warner JB, Bulyk ML. Short-term calorie restriction in male mice feminizes gene expression and alters key regulators of conserved aging regulatory pathways. PLoS One. 2009; 4: e5242.

174. Selman C, Tullet JM, Wieser D, Irvine E, Lingard SJ, Choudhury AI, Claret M, Al-Qassab H, Carmignac D, Ramadani F, Woods A, Robinson IC, Schuster E, Batterham RL, Kozma SC, Thomas G et al. Ribosomal protein S6 kinase 1 signaling regulates mammalian life span. Science. 2009; 326: 140-144.

175. Moskalev AA, Shaposhnikov MV. Pharmacological Inhibition of Phosphoinositide 3 and TOR Kinases Improves Survival of Drosophila melanogaster. Rejuvenation Res. 2010; 13: 246-247.

176. Bjedov I, Toivonen JM, Kerr F, Slack C, Jacobson J, Foley A, Partridge L. Mechanisms of life span extension by rapamycin in the fruit fly Drosophila melanogaster. Cell Metab. 2010; 11: 35-46.

177. Miller RA, Harrison DE, Astle CM, Baur JA, Boyd AR, de Cabo R, Fernandez E, Flurkey K, Javors MA, Nelson
JF, Orihuela CJ, Pletcher S, Sharp ZD, Sinclair D, Starnes JW, Wilkinson JE et al. Rapamycin, But Not Resveratrol or Simvastatin, Extends Life Span of Genetically Heterogeneous Mice. J Gerontol A Biol Sci Med Sci. 2011; 66: 191-201.

178. Anisimov VN, Zabezhinski MA, Popovich IG, Piskunova TS, Semenchenko AV, Tyndyk ML, Yurova MN, Antoch MP, Blagosklonny MV. Rapamycin extends maximal lifespan in cancer-prone mice. Am J Pathol. 2010; 176: 2092-2097.

179. Anisimov VN, Zabezhinski MA, Popovich IG, Piskunova TS, Semenchenko AV, Tyndyk ML, Yurova MN, Blagosklonny MV. Rapamycin increases lifespan and inhibits spontaneous tumorigenesis in inbred female mice. Cell Cycle. 2011; 10: 4230-4236.

180. Kapahi P, Chen D, Rogers AN, Katewa SD, Li PW, Thomas EL, Kockel L. With TOR, less is more: a key role for the conserved nutrient-sensing TOR pathway in aging. Cell Metab. 2010; 11: 453-465.

181. Blagosklonny MV. Rapamycin and quasi-programmed aging: Four years later. Cell Cycle. 2010; 9: 1859-1862.

182. Bjedov I, Partridge L. A longer and healthier life with TOR down-regulation: genetics and drugs. Biochem Soc Trans. 2011; 39: 460-465.

183. Katewa SD, Kapahi P. Role of TOR signaling in aging and related biological processes in Drosophila melanogaster. Exp Gerontol. 2011; 46: 382-390.

184. Liu M, Howes A, Lesperance J, Stallcup WB, Hauser CA, Kadoya K, Oshima RG, Abraham RT. Antitumor activity of rapamycin in a transgenic mouse model of ErbB2dependent human breast cancer. Cancer Res. 2005; 65: 5325-5336.

185. Mabuchi S, Altomare DA, Connolly DC, Klein-Szanto A, Litwin S, Hoelzle MK, Hensley HH, Hamilton TC, Testa JR. RAD001 (Everolimus) delays tumor onset and progression in a transgenic mouse model of ovarian cancer. Cancer Res. 2007; 67: 2408-2413.

186. Mosley JD, Poirier JT, Seachrist DD, Landis MD, Keri RA. Rapamycin inhibits multiple stages of c-Neu/ErbB2 induced tumor progression in a transgenic mouse model of HER2positive breast cancer. Mol Cancer Ther. 2007; 6: 21882197.

187. Granville CA, Warfel N, Tsurutani J, Hollander MC, Robertson M, Fox SD, Veenstra TD, Issaq HJ, Linnoila RI, Dennis PA. Identification of a highly effective rapamycin schedule that markedly reduces the size, multiplicity, and phenotypic progression of tobacco carcinogen-induced murine lung tumors. Clin Cancer Res. 2007; 13: 2281-2289.

188. Chollet P, Abrial C, Tacca O, Mouret-Reynier MA, Leheurteur M, Durando X, Cure H. Mammalian target of rapamycin inhibitors in combination with letrozole in breast cancer. Clin Breast Cancer. 2006; 7: 336-338.

189. Fierz Y, Novosyadlyy R, Vijayakumar A, Yakar S, LeRoith D. Mammalian target of rapamycin inhibition abrogates 
insulin-mediated mammary tumor progression in type 2 diabetes. Endocr Relat Cancer. 2010; 17: 941-951.

190. Robinson J, Lai C, Martin A, Nye E, Tomlinson I, Silver A. Oral rapamycin reduces tumour burden and vascularization in Lkb1(+/-) mice. J Pathol. 2009; 219: 35-40.

191. Khanna A, Kapahi P. Rapamycin: Killing two birds with one stone. Aging (Albany NY). 2011; 3: 1043-4.

192. Lashinger LM, Malone LM, Brown GW, Daniels EA, Goldberg JA, Otto G, Fischer SM, Hursting SD. Rapamycin partially mimics the anticancer effects of calorie restriction in a murine model of pancreatic cancer. Cancer Prev Res (Phila). 2011; 4: 1041-1051.

193. Kauffman HM, Cherikh WS, Cheng Y, Hanto DW, Kahan BD. Maintenance immunosuppression with target-ofrapamycin inhibitors is associated with a reduced incidence of de novo malignancies. Transplantation. 2005; 80: 883889.

194. Campistol JM, Eris J, Oberbauer R, Friend P, Hutchison B, Morales JM, Claesson K, Stallone G, Russ G, Rostaing L, Kreis H, Burke JT, Brault Y, Scarola JA, Neylan JF. Sirolimus Therapy after Early Cyclosporine Withdrawal Reduces the Risk for Cancer in Adult Renal Transplantation. J Am Soc Nephrol. 2006; 17: 581-589.

195. Stallone G, Schena A, Infante B, Di Paolo S, Loverre A, Maggio G, Ranieri E, Gesualdo L, Schena FP, Grandaliano G. Sirolimus for Kaposi's sarcoma in renal-transplant recipients. N Engl J Med. 2005; 352: 1317-1323.

196. Blagosklonny MV. Prevention of cancer by inhibiting aging. Cancer Biol Ther. 2008; 7: 1520-1524.

197. Dowling RJ, Zakikhani M, Fantus IG, Pollak M, Sonenberg N. Metformin inhibits mammalian target of rapamycindependent translation initiation in breast cancer cells. Cancer Res. 2007; 67: 10804-10812.

198. Vazquez-Martin A, Oliveras-Ferraros C, Menendez JA. The antidiabetic drug metformin suppresses HER2 (erbB2) oncoprotein overexpression via inhibition of the mTOR effector p70S6K1 in human breast carcinoma cells. Cell Cycle. 2009; 8: 88-96.

199. Kalender A, Selvaraj A, Kim SY, Gulati P, Brule S, Viollet B, Kemp BE, Bardeesy N, Dennis P, Schlager JJ, Marette A, Kozma SC, Thomas G. Metformin, independent of AMPK, inhibits mTORC1 in a rag GTPase-dependent manner. Cell Metab. 2010; 11: 390-401.

200. Ben Sahra I, Regazzetti C, Robert G, Laurent K, Le Marchand-Brustel Y, Auberger P, Tanti JF, GiorgettiPeraldi S, Bost F. Metformin, independent of AMPK, induces mTOR inhibition and cell-cycle arrest through REDD1. Cancer Res. 2011; 71: 4366-4372.

201. Dilman VM, Berstein LM, Zabezhinski MA, Alexandrov VA, Bobrov JF, Pliss GB. Inhibition of DMBA-induced carcinogenesis by phenformin in the mammary gland of rats. Arch Geschwulstforsch. 1978; 48: 1-8.

202. Dilman VM, Anisimov VN. Effect of treatment with phenformin, diphenylhydantoin or L-dopa on life span and tumour incidence in $\mathrm{C} 3 \mathrm{H} / \mathrm{Sn}$ mice. Gerontology. 1980; 26: 241-246.

203. Anisimov VN, Berstein LM, Egormin PA, Piskunova TS, Popovich IG, Zabezhinski MA, Kovalenko IG, Poroshina TE, Semenchenko AV, Provinciali M, Re F, Franceschi C. Effect of metformin on life span and on the development of spontaneous mammary tumors in HER-2/neu transgenic mice. Exp Gerontol. 2005; 40: 685-693.

204. Anisimov VN, Egormin PA, Bershtein LM, Zabezhinskii MA, Piskunova TS, Popovich IG, Semenchenko AV. Metformin decelerates aging and development of mammary tumors in HER-2/neu transgenic mice. Bull Exp Biol Med. 2005; 139: 721-723.

205. Anisimov VN, Berstein LM, Egormin PA, Piskunova TS, Popovich IG, Zabezhinski MA, Tyndyk ML, Yurova MV, Kovalenko IG, Poroshina TE, Semenchenko AV. Metformin slows down aging and extends life span of female SHR mice. Cell Cycle. 2008; 7: 2769-2773.

206. Anisimov VN. Metformin for aging and cancer prevention. Aging (Albany NY). 2010; 2: 760-774.

207. Anisimov VN, Piskunova TS, Popovich IG, Zabezhinski MA, Tyndyk ML, Egormin PA, Yurova MV, Rosenfeld SV, Semenchenko AV, Kovalenko IG, Poroshina TE, Berstein LM. Gender differences in metformin effect on aging, life span and spontaneous tumorigenesis in 129/Sv mice. Aging (Albany NY). 2010; 2: 945-958.

208. Anisimov VN, Egormin PA, Piskunova TS, Popovich IG, Tyndyk ML, Yurova MN, Zabezhinski MA, Anikin IV, Karkach AS, Romanyukha AA. Metformin extends life span of HER-2/neu transgenic mice and in combination with melatonin inhibits growth of transplantable tumors in vivo. Cell Cycle. 2010; 9: 188-197.

209. Memmott RM, Mercado JR, Maier CR, Kawabata S, Fox $\mathrm{SD}$, Dennis PA. Metformin prevents tobacco carcinogen-induced lung tumorigenesis. Cancer Prev Res (Phila). 2010; 3: 1066-1076.

210. Engelman JA, Cantley LC. Chemoprevention meets glucose control. Cancer Prev Res (Phila). 2010; 3: 1049-1052.

211. Evans JM, al e. Metformin and reduced risk of cancer in diabetic patients. BMJ. 2005; 330: 1304-1305.

212. Libby G, Donnelly LA, Donnan PT, Alessi DR, Morris AD, Evans JM. New users of metformin are at low risk of incident cancer: a cohort study among people with type 2 diabetes. Diabetes Care. 2009; 32: 1620-1625.

213. Berstein LM. Metformin, insulin, breast cancer and more. Future Oncol. 2009; 5: 309-312.

214. Berstein LM. Modern approach to metabolic rehabilitation of cancer patients: biguanides (phenformin and metformin) and beyond. Future Oncol. 2010; 6: 1313-1323.

215. He X, Esteva FJ, Ensor J, Hortobagyi GN, Lee MH, Yeung SC. Metformin and thiazolidinediones are associated with improved breast cancer-specific survival of diabetic women with HER2+ breast cancer. Ann Oncol. 2011.

216. Koch L. Cancer: Long-term use of metformin could protect 
against breast cancer. Nat Rev Endocrinol. 2010; 6: 356.

217. Pollak M. Metformin and other biguanides in oncology: advancing the research agenda. Cancer Prev Res (Phila). 2010; 3: 1060-1065.

218. Martin-Castillo B, Vazquez-Martin A, Oliveras-Ferraros C, Menendez JA. Metformin and cancer: doses, mechanisms and the dandelion and hormetic phenomena. Cell Cycle. 2010; 9: 1057-1064.

219. Zhang ZJ, Zheng ZJ, Kan H, Song Y, Cui W, Zhao G, Kip KE. Reduced risk of colorectal cancer with metformin therapy in patients with type 2 diabetes: a meta-analysis. Diabetes Care. 2011; 34: 2323-2328.

220. Gosmanova EO, Canada RB, Mangold TA, Rawls WN, Wall BM. Effect of metformin-containing antidiabetic regimens on all-cause mortality in veterans with type 2 diabetes mellitus. Am J Med Sci. 2008; 336: 241-247.

221. Kubota M, Shimizu M, Sakai H, Yasuda Y, Ohno T, Kochi T, Tsurumi H, Tanaka T, Moriwaki H. Renin-angiotensin system inhibitors suppress azoxymethane-induced colonic preneoplastic lesions in $\mathrm{C} 57 \mathrm{BL} / \mathrm{KsJ}-\mathrm{db} / \mathrm{db}$ obese mice. Biochem Biophys Res Commun. 2011; 410: 108-113.

222. Mansour MA, Al-Ismaeel H, Al-Rikabi AC, Al-Shabanah OA. Comparison of angiotensin converting enzyme inhibitors and angiotensin II type 1 receptor blockade for the prevention of premalignant changes in the liver. Life Sci. 2011; 89: 188-194.

223. Luo Y, Ohmori H, Shimomoto T, Fujii K, Sasahira T, Chihara Y, Kuniyasu H. Anti-angiotensin and hypoglycemic treatments suppress liver metastasis of colon cancer cells. Pathobiology. 2011; 78: 285-290.

224. Miyajima A, Kosaka T, Asano T, Seta K, Kawai T, Hayakawa M. Angiotensin II type I antagonist prevents pulmonary metastasis of murine renal cancer by inhibiting tumor angiogenesis. Cancer Res. 2002; 62: 4176-4179.

225. Chang CH, Lin JW, Wu LC, Lai MS. Angiotensin receptor blockade and risk of cancer in type 2 diabetes mellitus: a nationwide case-control study. J Clin Oncol. 2011; 29: 3001-3007.

226. Huang CC, Chan WL, Chen YC, Chen TJ, Lin SJ, Chen JW, Leu HB. Angiotensin II receptor blockers and risk of cancer in patients with systemic hypertension. Am J Cardiol. 2011; 107: 1028-1033.

227. Moscarelli L, Zanazzi M, Mancini G, Rossi E, Caroti L, Rosso G, Bertoni E, Salvadori M. Keratinocyte cancer prevention with ACE inhibitors, angiotensin receptor blockers or their combination in renal transplant recipients. Clin Nephrol. 2010; 73: 439-445.

228. Schelling P, Fischer H, Ganten D. Angiotensin and cell growth: a link to cardiovascular hypertrophy? J Hypertens. 1991; 9: 3-15.

229. Giasson E, Meloche S. Role of p70 S6 protein kinase in angiotensin II-induced protein synthesis in vascular smooth muscle cells. J Biol Chem. 1995; 270: 5225-5231.

230. Sadoshima J, Izumo S. Rapamycin selectively inhibits angiotensin II-induced increase in protein synthesis in cardiac myocytes in vitro. Potential role of $70-\mathrm{kD}$ S6 kinase in angiotensin II-induced cardiac hypertrophy. Circ Res. 1995; 77: 1040-1052.

231. Takano H, Komuro I, Zou Y, Kudoh S, Yamazaki T, Yazaki Y. Activation of p70 S6 protein kinase is necessary for angiotensin II-induced hypertrophy in neonatal rat cardiac myocytes. FEBS Lett. 1996; 379: 255-259.

232. Eguchi S, Iwasaki H, Ueno H, Frank GD, Motley ED, Eguchi K, Marumo F, Hirata Y, Inagami T. Intracellular signaling of angiotensin II-induced p70 S6 kinase phosphorylation at Ser(411) in vascular smooth muscle cells. Possible requirement of epidermal growth factor receptor, Ras, extracellular signal-regulated kinase, and Akt. J Biol Chem. 1999; 274: 36843-36851.

233. Haider UG, Sorescu D, Griendling KK, Vollmar AM, Dirsch VM. Resveratrol suppresses angiotensin II-induced Akt/protein kinase B and p70 S6 kinase phosphorylation and subsequent hypertrophy in rat aortic smooth muscle cells. Mol Pharmacol. 2002; 62: 772-777.

234. Yamakawa T, Tanaka S, Kamei J, Kadonosono K, Okuda K. Phosphatidylinositol 3-kinase in angiotensin II-induced hypertrophy of vascular smooth muscle cells. Eur J Pharmacol. 2003; 478: 39-46.

235. Kim JA, Jang HJ, Martinez-Lemus LA, Sowers JR. Activation of mTOR/p70S6 kinase by ANG II inhibits insulin-stimulated endothelial nitric oxide synthase and vasodilation. Am J Physiol Endocrinol Metab. 2011; 302: E201-208.

236. Whaley-Connell A, Habibi J, Panfili Z, Hayden MR, Bagree S, Nistala R, Hyder S, Krueger B, Demarco V, Pulakat L, Ferrario CM, Parrish A, Sowers JR. Angiotensin II activation of mTOR results in tubulointerstitial fibrosis through loss of N-cadherin. Am J Nephrol. 2011; 34: 115125.

237. Pasquier E, Ciccolini J, Carre M, Giacometti S, Fanciullino R, Pouchy C, Montero MP, Serdjebi C, Kavallaris M, Andre N. Propranolol potentiates the anti-angiogenic effects and anti-tumor efficacy of chemotherapy agents: implication in breast cancer treatment. Oncotarget. 2010; 2: 797-809.

238. Powe DG, Voss MJ, Zanker KS, Habashy HO, Green AR, Ellis IO, Entschladen F. Beta-blocker drug therapy reduces secondary cancer formation in breast cancer and improves cancer specific survival. Oncotarget. 2010; 1: 628-638.

239. Powe DG, Entschladen F. Targeted therapies: Using betablockers to inhibit breast cancer progression. Nat Rev Clin Oncol. 2011; 8: 511-512.

240. Melhem-Bertrandt A, Chavez-Macgregor M, Lei X, Brown EN, Lee RT, Meric-Bernstam F, Sood AK, Conzen SD, Hortobagyi GN, Gonzalez-Angulo AM. Beta-blocker use is associated with improved relapse-free survival in patients with triple-negative breast cancer. J Clin Oncol. 2011; 29: 2645-2652.

241. Barron TI, Connolly RM, Sharp L, Bennett K, Visvanathan 
K. Beta blockers and breast cancer mortality: a populationbased study. J Clin Oncol. 2011; 29: 2635-2644.

242. Schuller HM. Beta-adrenergic signaling, a novel target for cancer therapy? Oncotarget. 2010; 1: 466-469.

243. Simm A, Schluter K, Diez C, Piper HM, Hoppe J. Activation of $\mathrm{p} 70(\mathrm{~S} 6)$ kinase by beta-adrenoceptor agonists on adult cardiomyocytes. J Mol Cell Cardiol. 1998; 30: 2059-2067.

244. Pesce L, Guerrero C, Comellas A, Ridge KM, Sznajder JI. beta-agonists regulate $\mathrm{Na}, \mathrm{K}-\mathrm{ATP}$ ase via novel MAPK/ERK and rapamycin-sensitive pathways. FEBS Lett. 2000; 486: 310-314.

245. Pesce L, Comellas A, Sznajder JI. Beta-adrenergic agonists regulate Na-K-ATPase via p70S6k. Am J Physiol Lung Cell Mol Physiol. 2003; 285: L802-807.

246. Grau MV, Sandler RS, McKeown-Eyssen G, Bresalier RS, Haile RW, Barry EL, Ahnen DJ, Gui J, Summers RW, Baron JA. Nonsteroidal anti-inflammatory drug use after 3 years of aspirin use and colorectal adenoma risk: observational follow-up of a randomized study. J Natl Cancer Inst. 2009; 101: 267-276.

247. Chang ET, Froslev T, Sorensen HT, Pedersen L. A nationwide study of aspirin, other non-steroidal antiinflammatory drugs, and Hodgkin lymphoma risk in Denmark. Br J Cancer. 2011; 105: 1776-1782.

248. Burn J, Gerdes AM, Macrae F, Mecklin JP, Moeslein G, Olschwang S, Eccles D, Evans DG, Maher ER, Bertario L, Bisgaard ML, Dunlop MG, Ho JW, Hodgson SV, Lindblom A, Lubinski J et al. Long-term effect of aspirin on cancer risk in carriers of hereditary colorectal cancer: an analysis from the CAPP2 randomised controlled trial. Lancet. 2011; 378: 2081-2087.

249. Rothwell PM, Fowkes FG, Belch JF, Ogawa H, Warlow $\mathrm{CP}$, Meade TW. Effect of daily aspirin on long-term risk of death due to cancer: analysis of individual patient data from randomised trials. Lancet. 2011; 377: 31-41.

250. Flossmann E, Rothwell PM. Effect of aspirin on longterm risk of colorectal cancer: consistent evidence from randomised and observational studies. Lancet. 2007; 369: 1603-1613.

251. Tan XL, Reid Lombardo KM, Bamlet WR, Oberg AL, Robinson DP, Anderson KE, Petersen GM. Aspirin, nonsteroidal anti-inflammatory drugs, acetaminophen, and pancreatic cancer risk: a clinic-based case-control study. Cancer Prev Res (Phila). 2011; 4: 1835-1841.

252. Cole BF, Logan RF, Halabi S, Benamouzig R, Sandler RS, Grainge MJ, Chaussade S, Baron JA. Aspirin for the chemoprevention of colorectal adenomas: meta-analysis of the randomized trials. J Natl Cancer Inst. 2009; 101: 256266.

253. Law BK, Waltner-Law ME, Entingh AJ, Chytil A, Aakre ME, Norgaard P, Moses HL. Salicylate-induced growth arrest is associated with inhibition of p70s6k and downregulation of c-myc, cyclin D1, cyclin A, and proliferating cell nuclear antigen. J Biol Chem. 2000; 275: 38261-38267.

254. Hsing AW, Sakoda LC, Chua S, Jr. Obesity, metabolic syndrome, and prostate cancer. Am J Clin Nutr. 2007; 86: s843-857.

255. Reeves GK, Pirie K, Beral V, Green J, Spencer E, Bull D. Cancer incidence and mortality in relation to body mass index in the Million Women Study: cohort study. Bmj. 2007; 335: 1134.

256. Polak P, Cybulski N, Feige JN, Auwerx J, Ruegg MA, Hall MN. Adipose-specific knockout of raptor results in lean mice with enhanced mitochondrial respiration. Cell Metab. 2008; 8: 399-410.

257. Renehan AG, Tyson M, Egger M, Heller RF, Zwahlen M. Body-mass index and incidence of cancer: a systematic review and meta-analysis of prospective observational studies. Lancet. 2008; 371: 569-578.

258. van Kruijsdijk RC, van der Wall E, Visseren FL. Obesity and cancer: the role of dysfunctional adipose tissue. Cancer Epidemiol Biomarkers Prev. 2009; 18: 2569-2578.

259. Donohoe CL, Doyle SL, Reynolds JV. Visceral adiposity, insulin resistance and cancer risk. Diabetol Metab Syndr. 2011; 3: 12.

260. Hursting SD, Lashinger LM, Wheatley KW, Rogers CJ, Colbert LH, Nunez NP, Perkins SN. Reducing the weight of cancer: mechanistic targets for breaking the obesitycarcinogenesis link. Best Pract Res Clin Endocrinol Metab. 2008; 22: 659-669.

261. Tremblay F, Brule S, Hee Um S, Li Y, Masuda K, Roden M, Sun XJ, Krebs M, Polakiewicz RD, Thomas G, Marette A. Identification of IRS-1 Ser-1101 as a target of S6K1 in nutrient- and obesity-induced insulin resistance. Proc Natl Acad Sci U S A. 2007; 104: 14056-14061.

262. Tremblay F, Marette A. Amino acid and insulin signaling via the $\mathrm{mTOR} / \mathrm{p} 70$ S6 kinase pathway. A negative feedback mechanism leading to insulin resistance in skeletal muscle cells. J Biol Chem. 2001; 276: 38052-38060.

263. Avruch J, Hara K, Lin Y, Liu M, Long X, Ortiz-Vega S, Yonezawa K. Insulin and amino-acid regulation of mTOR signaling and kinase activity through the Rheb GTPase. Oncogene. 2006; 25: 6361-6372.

264. Inoki K, Guan KL. Complexity of the TOR signaling network. Trends Cell Biol. 2006; 16: 206-212.

265. Moore T, Beltran L, Carbajal S, Strom S, Traag J, Hursting SD, DiGiovanni J. Dietary energy balance modulates signaling through the Akt/mammalian target of rapamycin pathways in multiple epithelial tissues. Cancer Prev Res (Phila). 2008; 1: 65-76.

266. Sengupta S, Peterson TR, Laplante M, Oh S, Sabatini DM. mTORC1 controls fasting-induced ketogenesis and its modulation by ageing. Nature. 2010; 468: 1100-1104.

267. Um SH, Frigerio F, Watanabe M, Picard F, Joaquin M, Sticker M, Fumagalli S, Allegrini PR, Kozma SC, Auwerx J, Thomas G. Absence of S6K1 protects against age- and diet-induced obesity while enhancing insulin sensitivity. 
Nature. 2004; 431: 200-205.

268. Khamzina L, Veilleux A, Bergeron S, Marette A. Increased activation of the mammalian target of rapamycin pathway in liver and skeletal muscle of obese rats: possible involvement in obesity-linked insulin resistance. Endocrinology. 2005; 146: 1473-1481.

269. Dann SG, Selvaraj A, Thomas G. mTOR Complex1-S6K1 signaling: at the crossroads of obesity, diabetes and cancer. Trends Mol Med. 2007; 13: 252-259.

270. Ma L, Ma S, He H, Yang D, Chen X, Luo Z, Liu D, Zhu Z. Perivascular fat-mediated vascular dysfunction and remodeling through the AMPK/mTOR pathway in high-fat diet-induced obese rats. Hypertens Res. 2010; 33: 446-453.

271. Dazert E, Hall MN. mTOR signaling in disease. Curr Opin Cell Biol. 2011.

272. Zoncu R, Efeyan A, Sabatini DM. mTOR: from growth signal integration to cancer, diabetes and ageing. Nat Rev Mol Cell Biol. 2011; 12: 21-35.

273. Romanov VS, Abramova MV, Svetlikova SB, Bykova TV, Zubova SG, Aksenov ND, Fornace AJ, Jr. , Pospelova TV, Pospelov VA. p21(Waf1) is required for cellular senescence but not for cell cycle arrest induced by the HDAC inhibitor sodium butyrate. Cell Cycle. 2010; 9: 3945-3955.

274. Shaw RJ, Cantley LC. Ras, PI(3)K and mTOR signalling controls tumour cell growth. Nature. 2006; 441: 424-430.

275. Janes MR, Fruman DA. Targeting TOR dependence in cancer. Oncotarget. 2010; 1: 69-76.

276. Markman B, Dienstmann R, Tabernero J. Targeting the $\mathrm{PI} 3 \mathrm{~K} / \mathrm{Akt} / \mathrm{mTOR}$ pathway--beyond rapalogs. Oncotarget. 2010; 1: 530-543.

277. Cully M, You H, Levine AJ, Mak TW. Beyond PTEN mutations: the PI3K pathway as an integrator of multiple inputs during tumorigenesis. Nat Rev Cancer. 2006; 6: 184192.
278. Guertin DA, Sabatini DM. Defining the role of mTOR in cancer. Cancer Cell. 2007; 12: 9-22.

279. Courtney KD, Corcoran RB, Engelman JA. The PI3K pathway as drug target in human cancer. J Clin Oncol. 2010; 28: 1075-1083.

280. Schmidt-Kittler O, Zhu J, Yang J, Liu G, Hendricks W, Lengauer C, Gabelli SB, Kinzler KW, Vogelstein B, Huso DL, Zhou S. PI3Kalpha inhibitors that inhibit metastasis. Oncotarget. 2010; 1: 339-348.

281. Dbouk HA, Backer JM. A beta version of life: p110beta takes center stage. Oncotarget. 2010; 1: 729-733.

282. Martelli AM, Evangelisti C, Chiarini F, McCubrey JA. The phosphatidylinositol 3-kinase/Akt/mTOR signaling network as a therapeutic target in acute myelogenous leukemia patients. Oncotarget. 2010; 1: 89-103.

283. Zawel L. P3Kalpha: a driver of tumor metastasis? Oncotarget. 2010; 1: 315-316.

284. Fujishita T, Aoki M, Taketo MM. The role of mTORC1 pathway in intestinal tumorigenesis. Cell Cycle. 2009; 8: 3684-3687. 